\title{
Intertekstual Novel Di Bawah Lindungan Ka'bah Karya Hamka dan Perempuan Berkalung Sorban Karya Abidah El Halieqy
}

\author{
Eulis Kulsum Halwati ${ }^{1)}$ \\ Universitas Indraprasta PGRI \\ Jalan Nangka No. 58 C/TB. Simatupang, Tanjung Barat, Jakarta Selatan 12530 \\ Sumaryoto ${ }^{2}$ \\ Universitas Indraprasta PGRI \\ Jalan Nangka No. 58 C/TB. Simatupang, Tanjung Barat, Jakarta Selatan 12530 \\ Bambang Sumadyo ${ }^{3)}$ \\ Universitas Indraprasta PGRI \\ Jalan Nangka No. 58 C/TB. Simatupang, Tanjung Barat, Jakarta Selatan 12530 \\ kulsumhalwati@gmail.com ${ }^{1)}$
}

\begin{abstract}
This study aims to describe the intertextuality between the novel Di Bawah Lindungan Kabah by Hamka and Perempuan Berkalung Sorban by Abidah El Halieqy. The study conducted by descriptive-qualitatif research, with intertextual theory approach. This research result showed that novel Perempuan Berkalung Sorban has intertextuality relationship with novel Di Bawah Lindungan Kabah as hypograme in theme, plot, and point of view.
\end{abstract}

Keyword: intertextual, novel

\begin{abstract}
Abstrak
Penelitian ini bertujuan untuk memaparkan hubungan intertekstualitas antara novel Di Bawah Lindungan Kabah karya Hamka dan Perempuan Berkalung Sorban karya Abidah El Halieqy. Penelitian ini menggunakan penelitian kualitatif-deskriptif dengan pendekatan teori intertekstual. Hasil kajian menunjukkan bahwa Perempuan Berkalung Sorban memiliki hubungan intertekstual dengan novel Di Bawah Lindungan Kabah sebagai hipogramnya dalam hal tema, alur dan sudut pandang.
\end{abstract}

Kata kunci: intertekstual, novel

\section{PENDAHULUAN}

Sastra adalah ciptaan kreatif imajinatif manusia bertolak dari kehidupan nyata yang ditulis atau dicetak serta memiliki ekspresi estetis, misalnya puisi, drama, dan cerita rekaan. Ekspresi estetis merupakan upaya pengeluaran pengalaman, perasaan. dan pikiran dari dalam diri manusia. Sebuah karya sastra baik puisi maupun prosa, mempunyai hubungan sejarah anlara karya sezaman yang mendahuluinya atau setelahnya. hubungan tersebut mencakup baik berupa hubungan persamaan maaupun pertentangan. Semua itu disebabkan karena sebuah teks karya sastra tidak lahir dalam kekosongan. tetapi senantiasa berada di antara teks-teks lain yang mendahuluinya sehingga antara teks yang kemudian dan teks sebelumnya terjalin relasi intertekstual (Teeuw, I983:65).

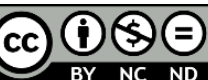

Creative Commons Attribution-NonCommercial-NoDerivatives 4.0 International License 
Sastra lama yang tertuang dalam naskah lama, adalah sebagian warisan dari rohani bangsa Indonesia. Warisan itu berupa ide, cita cita, dan pernyataan sikap nenek moyang yang turun-temurun (Robson, 1978:5). Warisan tersebut berperan sangat besar dalam pembangunan mental dan spiritual bangsa, menuju pembangunan manusia seutuhnya. Disamping menjadi bacaan hiburan. sastra lama juga mengandung unsur pendidikan. Pengertian sastra lama mencakup semua yang tertulis dan terungkap dalam naskah-naskah lama. Kondisi yang demikian itulah menjadikan bentuk dan isinya cukup beragam. Dalam bentuk karya sastra, banyak ditemukan naskah yang berisi hikayat, dongeng, syair pantun, dan banyak jenis lain yang lebih spesifik lagi. Disarnping itu ada banyak naskah yang membentangkan masalah undang-undang, adat istiadat, sejarah, cara membuat obat dan sebagainya (Djamaris, 1997: 211).

Dalam kehidupan sastra, sastra lama sangat membantu penciptaana karya sastra modern. Karena pcngaruh dalam penciptaan karya tersebut. Sering terjadi hubungan intertekslualitas dalam karya sastra. Setidaknya ada empat aspek kesinambungan yang terjadi antara sastra lama dengan sastra baru sebagaimana dikemukakan Teeuw (1982: 12), yaitu : (1) banyak karya sastra baru merupakan transformasi teks lama dalam bentuk saduran, Salinan, dan sebagainya, (2) penggunaan tema tradisional sering rnenonjol dalarn sastra modern: (3) dalam karya sastra modern sering terungkap dasar kebudayaan tradisional maupun konllik nilai dalarn penghayatan manusia moderen; dan (4) munculnya gejala poetry reading atau alau dipakainya sastra sebagai performing arts

Hubungan interteks dalam karya sastra tidak dapat dipungkiri, karena tidak ada sebuah teks manapun yang mandiri. Dalarn proses pcnciptaan dan pembacaannya, keberadaan suatu teks tidak dapat dilakukan tanpa adanya teks-teks lain sebagai contoh, teladan, kerangka dan seterusnya (Teeuw 1983: 145-146). Intertekstualitas cakupannya cukup luas sebab hal itu mencakup pula bentuk-bentuk penyalinan, penyaduran. penyadapan, dan penerjermahan. Hal ini berlaku pula pada karya sastra yang bersifat diturunkan secara lisan maupun tulisan.

Keterkaitan antarteks dalam sastra lama di Indonesia telah banyak dilakukan sebelumnya. Sastrowardoyo (1983:165-167) memperlihatkan pengaruh sastra Hindia Belanda Max Havelaar di dalam Atheis melalui pemakaian gaya penulisan cerita berbingkai Max Havelaar, yakni mengembangkan cerita berdasarkan naskah yang diberikan oleh tokoh cerita kepada narrator. Secara genetis, karya sastra tradisi Balai Pustaka juga memperlihatkan kehadiran karya-karya sastra Hindia Belanda dan sastra non-Balai Pustaka, khususnya cerita para nyai. Pradopo (2003:181-183) melihat Azab dan Sengsara telah menjadi acuan (hipogram) bagi novel-novel Indonesia tradisi Balai Pustaka lainnya, seperti Siti Nurbaya, Kalau Tak Untung, dan Di Bawah Lindungun Kabah. Khususnya dalam struktur cerita dan pokok gagasan adat kawin paksa. Novel Di Bawah Lindungan Kabah, Atheis, dan Gairah untuk Hidup dan untuk Mati menunjukkan kaitan intertekstual dalam hal pusat pengisahan dan struktur ceritanya (Pradopo. 2003:168), sedangkan Siti Nurbaya. Layar Terkemhang, dan Belenggu menunjukkan dialog antarteks dalam hal masalah emansipasi perempuan. Di samping genre prosa, Pradopo (2002: 236252) juga memaparkan hubungan antarteks sajak-sajak Chairil Anwar dengan Amir Hamzah dan sajak-sajak generasi setelah Chairil Anwar. Sebuah kajian interteks 
pada sastra lama juga telah dilakukan terhadap teks sejarah Melayu oleh Junus (1984). Dalam penelitiannya, Yunus mengungkap adanya hubungan interteks Sejarah Melayu dengan Hikayat Hang Tuah, kisah nabi-nabi, dan teks-teks lain.

Dialog antarteks tidak hanya terjadi antara karya-karya pengarang yang berbeda, tetapi juga dapat dilihat pada karya sastra dari pengarang yang sama sebagaimana dikemukakan Gyem (2005: 29) berkaitan dengan intertekstualitas novel Tak Ada Esok, Jalan Tak Ada Ujung, Senja di Jakarta. Tanah Gersang, Harirnau- Harimau, dan Maut dan Cinta karya Mochtar Lubis. Keenam novel tersebut memperlihatkan tiga bentuk hubungan interteks, yaitu hubungan tansformatif, hubungan dialektis, dan hubungan hipogramatik. Dalarn kerangka intertektualitas, kemerosotan moral dalam Senja di Jakarta tidak dapat dipahami dengan baik tanpa membaca Tak Ada Esok, Jalan Tak Ada Ujung, dan Tanah Gersang.

Pada perkembangan teori intertekstual ini, Riffaterre (1978:23) menyebut teks-teks yang melatari atau mendasari terciptanya suatu karya sastra sebagai hipogram. Hipogram dapat membantu pembaca atau peneliti untuk mengenali aspek-aspek yang diserap ke dalam karya sastra yang terbit lebih kemudian atau teks transformasi dengan cara membandingkannya.

Novel Di Bawah Lindungan Kabah karya Hamka (1938) merupakan salah satu novel lama yang terkenal, bahkan sempat dienkranasi meniadi sebuah Film pada tahun 2011. Sebagaimana diebutkan oleh Pradopo (2003: 181- 183) di atas bahwa novel Di Bawah Lindungan Kabah karya Hamka merupakan sebuah novel yang mengusung adat kawin paksa. Jika dikaji lebih lanjut, selain mengusung tradisi kawin paksa, novel tersebut juga mengusung tradisi "pinggitan". Dimana tradisi pinggitan tersebut merupakan budaya pembatasan pergaulan dan pendidikan bagi kaum perempuan yang mulai menginjak dewasa (Zulhelmi, 2016). Gagasan yang mengusung tradisi kawin paksa dan pinggitan ke dalam tema sebuah karya novel. masih dapat ditemui dalam karya-karya novel modern, seperti novel Perenrpuan Berkalung Sorban karya Adibah El Halieqy tahun 2001. Novel Perempuan Berkalung Sorban juga merupakan novel terkenal, dan pernah dirilis menjadi sebuah film berjudul sama pada tahun 2009.

Berdasarkan adanya kesamaan tradisi yang diusung, yaitu tradisi kawin paksa dan tradisi pinggitan, di dalam cerita novel Di Bawah Lindungan Kabah yang terbit tahun (1937) dan novel Perempuan Berkalung Sorban (2001), artikel ini bertujuan mengkaji tingkat hubungan interiekstualitas kedua novel berbeda zaman tersebut.

\section{METODE}

Metode Penelitian Metode yang digunakan dalam penelitian ini yaitu metode deskriptif-kualitatif dengan menggunakan pendekatan intertekstual. Peneliti menjelaskan persamaan dan perbedaan unsur-unsur struktur pembentuk novel (Tema, Alur/Plot, Tokoh dan Sudut Pandang) dari kedua novel yang dikaji.

Metode pengumpulan data penelitian dilakukan dengan studi kepustakaan dengan teknik membaca, mencatat, dan mengklasifikasi data-data yang terdapat dalam kedua teks tersebut. Setelah data-data terkumpul, data-data tersebut akan 
dianalisis dengan menggunakan pendekatan intertekstual. Pendekatan ini digunakan untuk melihat hubungan kedua teks, yakni hubungan teks transformasi dengan hipogramnya. Anlisis intertekstual dibatasi pada unsur-unsur pembentuk novel yaitu: tema, alut/plot, tokoh, dan sudut pandang.

\section{HASIL DAN PEMBAHASAN}

\section{Intertekstual dalam Tema/Gagasan}

Di dalam realita kehidupan masyarakat, umumnya banyak bentuk kegiatan sehari-hari yang dianggap tidak boleh atau tidak pantas dilakukan oleh seorang anak perempuan, yang bisa jadi berbeda di setiap daerahnya. Semua itu berhubungan dengan tradisi pinggitan terhadap seorang anak peremuan sesudah masuk usia gadis. Selain membatasi aktifitas di luar maupun di dalam rumah, juga tradisi pinggitan membatasi dalam hal pendidikan, baik jenjang maupun jenis pendidikannya. Hamka di dalam novel $D B L K$ mengungkapkan permasalahan tradisi pinggitan ini dalam kehidupan tokoh Zainab, seperti yang tercantum dalam teks berrikut ini:

“.... Saya masih teringat nikmat kehidupan dalam dunia anak-anak yang kerap diratapi oleh ahli-ahli syair, yang hanya datang sekali kea lam amnusia semasa hidupnya. ... jika pulang dari sekolah, ssaya dan Zainab bersama teman-teman kami yang lain berlari-lari bermain galah dalam pekarangan rumahnya, memanjat pohon rambutan yang sedang ranum, kadang-kadang bercari-carian, dan bersorak-sorak. Di sore hari kami duduk di beranda depan, mambalik-balikan buku gamabar, bertengkar dan berkelahi, kemudian damai pula. Hari minggu kami diijinkan perhi ke tepi laut, ke Muara atau ke tepi Batang Arau, melihat perahu pengail yang sedang dikatung-katungkan gelombang di tengah samudera luas. Kain layarnya dipuput oleh angin mengantarkannya ke tengah..... Negeri Pariaman hijau tampak dari jauh. Ombak memecah dan menderum tiada henti memukuli tepi pasir itu. Di sana kami berlari-lari mengejar ambaiambai yang sigap dan lekas lari ke sarangnya. Kadang-kadang kami perbuat unggunan pasir.... Tiba-tiba datang ombak yang agak besar, dihapuskannya unggunan kami. Anak-anak perempuan lari ke tepi menyingsingkan tepi bajunya, ...." (Di Bawah Lindungan Kabah: 22-23).

"Dari sekolah rendah Hollands Inlandsce School (HIS) saya sama-sama naik dengan anaknya menduduki Meer Uitgebreid Lager Onderwijs (MULO).... Zainab pun himgga itu pelajarannya karena dalam adat orang hartawan dan bangsawan Padang, kemajuan anak perempuan itu hanyaterbatas hungga MULO. Belum berani mereka keluar dari kebiasaan umum, melepaskan anak perempuannya belajar jauh-jauh. Setelah tamat dari MULO, menurut adat, Zainab masuk pinggitan. Ia tidak akan dapat keluar lagi kalua tidak ada keperluan yang sangat penting. Itupun harus ditemani oleh ibu atau kepercayaannya sampai dating masanya bersuami." (Di Bawah Lindungan Kabah: 23-24). 
"'Yang berasa sedih amat adalah anak-anak perernpuan yang akan masuk pingitan. Tamat sekolah bagi mereka berarti suatu sangkar yang telah tersedia buat seekor burung yang bebas terbang. Zainab sendiri, sejak tamat sekolah, tetap dalam rumah, didatangkan baginya guru dari luar yang akan mengajarkan berbagai-bagai kepandaian yang perlu bagi anakanak perempuan, seperti mencuci, merenda, memasak, dan lain-lain. Petang hari ia menyambung pelajarannya dalam perkara agama." (Di Bawah Lindungan Kabah: 26).

Berbeda dengan Hamka, Adibah El Halieqy dalam mengusung gagasan tradisi pinggitan ini dalam tema novelnya dilakukan dengan lebih tegas dan penuh dengan ketidaksetujuan, baik dalam dialog maupun fikiran sang tokoh utamanya yaitu Annisa. Sebagaimana yang tercantum dalam beberapa kutipan di bawah ini:

" Ow...ow...ow..jadi begitu. Apa Ibu belum mengatakan padamu kalau naik kuda hanya pantas dipelajari oleh kakakmu Rizal, atau kakakmu Wildan. Kau tahu, mengapa? Sebab kau ini anak perempuan, Nisa. Nggak pantas, anak perempuan kok naik kuda. "pencilakan”, apalagi keluyuran mengelilingi ladang sampai ke blumbang segala." (Perempuan Berkalung Sorban: 7).

" Yang aneh apanya, Bu. Pak guru bilang kewajiban seorang perempuan itu banyak sekali, ada mencuci, memasak. mengepel. menyapu, menyuapi, menyusui, memandikan dan banyak lagi. Tidak seperi laki-laki, Bu. Kewajibannya. Cuma satu, pergi ke kantor. Mudah dihafalkan. Mengapa dulu aku tidak taki-laki saja Bu? Aku ingin pergi ke kantor. Aku juga tidak suka memasak di dapur, bau bawang, bau terasi dan asap mengepul. Aku ingin belajar naik kuda seperti Rizal. Boleh kan, Bu?" (Perempuan Berkalung Sorban: 14.).

".. Ah. Betapa bodohnya aku. Jika semua itu harus menjadi bagian dari hidupku. Betapa malangnya menjadi seorang perempuan, jika sampai mati harus tidak boleh menolak semua yang bertentangan dengan hati nurani, " (Perempuan Berkalung Sorban: 78).

Berdasarkan uraian di atas, dapat dikatakan bahwa novel Perempuan Berkalung Sorban merupakan transformasi yang bersifat pengembangan dari novel Di Bawah Lindungan Ka'bah sebagai hipogramnya dalam hal pembatasan aktivitas anak perempuan dan tradisi pinggitan. Selain tradisi pinggitan, kedua novel samasama mengangkat tradisi kawin paksa terhadap anak gadis, tanpa meminta persetujuannya terlebih dahulu. Gagasan tradisi kawin paksa ini pula yang menjadi sumber kekuatan dalam cerita yang disajikan oleh kedua pengarang di atas.

Dalam novel Di Bawah Lindungan Ka'bah, Zaynab, seorang gadis yang berasal dari kelas masyarakat atas dipaksakan menikah dengan kemenakan ayahnya yang berasal dari kelas masyarakat yang sama. Padahal, Zaynab telah jatuh cinta pada seorang pemuda yang berasal dari kelas masyarakat bawah, Hamid. Kedua pasangan manusia ini (Zaynab dan Hamid), memiliki perasaan saling menyintai. Namun karena Hamid berasal dari kelas masyarakat yang berbeda, hubungan

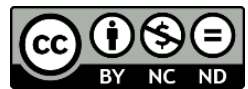


percintaan mereka harus kandas di tengah jalan. Ibunda Zaynab justru meminta kesediaan Hamid, yang sudah dianggap sebagai anak angkatnya, supaya membujuk Zaynab untuk mau menikah dengan calon yang telah direncanakan olehnya. Akhirnya, dengan sangat terpaksa Hamid melakukan hal tersebut, walaupun sangat bertentangan dengan hati nuraninya. Ia tidak mau dianggap sebagai anak yang tidak tahu rasa berterimakasih atas jasa-jasa orang tua Zaynab yang selama ini menanggung kehidupannya. Setelah melaksanakan tugas tersebut, Hamid pergi meninggalkan kampung halaman demi menguburkan kenangan indah bersama Zaynab.

Sementara Zainab, tetap pada pendiriannya yaitu tidak mau menikah dengan calon yang dipersiapkan ibunya. Pemuda yang akan dijodohkanyapun menerima penolakan Zaynab dengan hati yang tulus. Sehingga ketika Hamid sudah hijrah dari kampung halaman, Zaynab larut dalam kesedihan dan membuatnya sakit, hingga akhirnya meninggal dunia. Demikian juga halnya dengan Hamid yang telah berhijrah menuju Mekkah al-Mukarramah, ia meninggal dunia tepat di bawah bangunan suci umat Islam, Ka'bah. Hamid meninggal karena tidak sanggup menahan emosinya ketika mendapatkan kabar tentang kematian Zaynab melalui teman karibnya yang sedang melaksanakan ibadah haji. Akhirnya, cinta sepasang anak manusia tidak kesampaian dan keduanya meninggalkan dunia yang fana ini.

Beberapa kutipan cerita yang menuturkan tentang cerita kawin paksa, dan kegagalan kedua insan yang saling mencinta (Zainab dan Hamid) untuk dipersatukan dalam sebuah perkawinan:

"Mustahil dia akan dapat menerima cinta saya karena dia langit dan ini bumi. Bangsanya tinggi dan saya hidup darinya tempat buat lekat hati Zainab." (Di Bawah Lindungan Kabah: 31).

" Hapuslah perasaan itu dari hatimu ... engkau tentu memikirkan juga bahwa emas tak setara Loyang, sutra tak sebangsa dengan benang." (Di Bawah Lindungan Kabah:36)

" Segala kaum kerabat di darat telah bermufakat dengan Mamak hendak mempertalikan Zainab dengan seorang kemenakan almarhum bapak, yang ada di darat itu. Dia sekarang sedang bersekolah di Jawa. Maksud mereka dengan perkawinan itu supaya harta benda almarhum bapaknya dapat dijagai oleh kaum keluarga sendiri, oleh kemenakan. Sebab tidak ada saudara Zainab yang lain... " (Di Bawah Lindungan Kabah :46-47).

"Ia diminta oleh ibuku melembutkan hati saya supaya saya sudi bersuami. Ia menjatuhkan perintah dan hukuman kepada diriku supaya saya dipunyai oleh orang lain. Tetapi nyata olehku bahwa dia menjatuhkan perintah itu dengan gugup, keringat mengalir di keningnya, seakan-akan ia mengerjakan sesuatu pekerjaan yang amat berlawanan dengan hatinya. Setelah saya menyatakan tak sanggup menuruti permintaannya, ia menarik nafas panjang dan berenung. Ia pulang ke rumahnya, dan semenjak itu dia tak datang-datang lagi." (Di Bawah Lindungan Kabah: 68) 
"Semenjak itu, entah dia di lautan atau di daratan... kian lama dia hilang, kian berdiri dalam ingatanku. Kadang-kadang saya menjadi seorang yang putus pengharapan... Melihat keadaanku demikian, rupanya ibuku pun kasihan, perhitungan hendak mengawinkan aku tiada menjadi pembicaraan lagi. Syukurlah kemenakan ayahku seorang yang berpengetahuan tinggi. Ketika dia singgah kemari dengan terus terang saya katakan bahwa dia lebih baik menjadi saudaraku daripada menjadi suamiku, ia menerima dengan hati yang suci." (Di Bawah Lindungan Ka'bah: 69).

Di dalam novel Perempuan Berkalung Sorban, Abidah El Halieqy tidak mengikuti Hamka yang menolak secara halus tradisi kawin paksa. Abidah justru melangsungkan terjadinya tradisi kawin paksa pada tokoh utamanya yaitu Annisa. Annisa dijodohkan dengan Samsudin. Samsudin merupakan sorang anak dari seorang Kiyai sahabat ayahnya. Annisa baru kenal pemuda itu pada saat akan berlangsungnya akad nikah. Annisa tak bisa menolak, walaupun dia telah memiliki pria idamannya, yaitu Lek Khudori, yang sedang menimba ilmu di Kairo Mesir. Abidah melakukan suatu transformasi yang bersifat konversi dari Di Bawah Lindungan Kabah sebagai hipogramnya. Dengan transformasi seperti ini, Abidah membawa tokoh Annisa untuk mengalami berbagai peristiwa menyakitkan dalam perkawinannya. Dimulai dari kekerasan seksual, sampai harus mengalami poligami oleh suaminya. Perceraianpun terjadi, dan Annisa ahirnya menikah untuk kedua kalinya dengan pria idamannya dulu yaitu Lek Khudori. Perkawinan keduanya menghasilkan seorang anak yang bernama Mahbub. Di ahir cerita, Annisa kembali harus mengalami peristiwa menyedihkan, yaitu meninggalnya Lek Khudori., dengan dugaan bahwa Samsudin yang menjadi penyebab kematian Khudori.

" .... Terbayang kembali peristiwa pahit yang mengawali pernikahanku dengan Samsudin, laki-laki yang baru kulihat wajahnya hanya satu jam sebelum akad nikah dilaksanakan. Tetapi lbu kembali berbisik. Nisa cobalah mulai mengaguminya dan jangan cemberut... la seorang sarjana hukum dan putra seorang kiayi ternama. Apalagi yang kurang dari dirinya. Segalanya ia miliki.." (Perempuan Berkalung Sorban:104-105)

\section{Intertekstual dalam Alur/Plot}

Boulton (1984: 45) mengatakan bahwa plot berarti seleksi peristiwa yang disusun dalam urutan waktu yang menjadi penyebab mengapa seseorang tertarik untuk membaca dan mengetahui kejadian yang akan datang. Dengan adanya sebab akibat logis tersebut, sebuah cerita novel mempunyai kesatuan dalam keseluruhan sehingga plot merupakan pengorganisasian bagian-bagian penting dalam cerita novel. Dengan perkataan lain, bahwa plot di dalam suatu novel, merupakan kreasi seoarang narator (pengarang) dalam merangkai peristiwa-peristiwa penting sehingga membentuk suatu cerita yang utuh. Untuk mengetahui bagaimana seorang pengarang menyusun plot/alur cerita, perlu diketahui cerita (strory) yang susungguhnya, yaitu peristiwa yang terjadi sesuai dengan tokoh dan urutan tatawaktu sebenarnya.

Urutan peristiwa yang terjadi sesuai dengan urutan wktunya yang ada di dalam novel Di Bawah Lindungan Kabah adalah sebagai berikut:

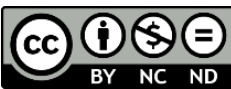


1. Hamid adalah Seorang anak yatim sejak umur 4 tahun, dan tinggal berdua dengan Ibunya. Biasa berjualan keliling.

2. Adanya warga baru bernama Haji Jafar. Menempati sebuah rumah besar bersama istrinya (Mak Asiyah) dan anak perempuan semata wayang bernama Zainab.

3. H. Jafar mengangkat Hamid sebagai anak angkatnya dan membiayai sekolahnya. Hamid juga sekaligus temannya Zainab baik teman bersekolah maupun bermain.

4. Hamid dan Zainab bersekolah dari mulai HIS sampai dengan MULO. Setelah menamatkan pendidikan samapai MULO, Hamid melanjutkan pendidikannya ke Padang Panjang pad Pendidikan Ilmu Agama. Sedangkan Zainab menjalani tradisi pinggitan di rumahnya.

5. Peristiwa meninggalnya H. Jafar ayahnya Zainab

6. Hamid pun harus kembali ke kampung mengurus ibunya yang sedang sakit, dan ahirnya meninggal.

7. Rencana perjodohan Zainab dengan kemenakan ayahnya. Hamid diperintahkan untuk membujuk Zainab untuk menerima perjodohan tersebut

8. Zainab menolak perjodohan tersebut

9. Hamid pergi meninggalkan kampung halamannya setelah melaksanakan perintah membujuk Zainab. Hamid merantau sampai ke Mekkah.

10. Rencana perjodohan Zainab tak berlangsung, karena pemuda yang akan dijadikan jodohnya menerima dengan hati yang tulus untuk tetap menjadi saudara. Zainab menderita memikirkan Hamid.

11. Satu tahun setelah itu, awal Ramadhan tahun 1927 di Mekah, Hamid bertemu dengan seorang Jemaah haji asal Sumatera, tokoh "saya", dan mereka bersahabat,

12. Dua bulan setelah itu, Hamid bertemu dengan Saleh yang akan melaksanaka ibadah haji, ia sahabatnya di Kampung, dan juga sedang melaksanakan studi di Mesir. Saleh merupakan suami dari Rosna sahabat Zainab.

13. Saleh bercerita tentang obrolan Rosna dengan Zainab. Saleh pun mengirim surat kepada Rosna tentang pertemuannya dengan Hamid.

14. Setelah pertemuan dengan Saleh, terjadi perobahan perilaku Hamid. Tokoh 'saya' memberanikan diri untuk menayakan tentang apa yang telah terjadi. Hamid bercerita tentang apa yang menjadi penyebab kesedihannya. Terjadi perjanjian diantara keduanya, yaitu: Hamid mengjinkan ceritanya untuk dibuatkan sebuah hikayat jika dia meninggal terlebih dahulu dari pada "Saya". Sebaliknya tetap menjadi rahasia berdua.

15. Sebelum berangkat wukuf ke Padang Arafah, datang surat dari Zainab untuk Hamid, dan bersamaan dengan datangnya surat dari Rosna untuk Zainab.

16. Sehabis wukuf di Arafah, kondisi Kesehatan Hamid terlihat semakin memburuk. 
17. Sebelum mengerjakan thawaf, mengelilingi Kabah, datang surat kawat dari Rosna, berisikan kabar bahwa Zainab telah meninggal dunia.

18. Dengan menggunakan tandu, Hamid berthawaf, dan diahir putaran dia turun dan memegang kain kiswah, setelah berdoa, dia meninggal dunia.

19. Tokoh 'Saya", dan Saleh sehari sebelum meninggalkan Mekah, berziarah ke Pekuburan Ma'ala, temapat Hamid dimakamkan. Setelah berdoa, Saleh berlayar ke Mesir, dan 'Saya' menuju ke Tanah Air.

20. Surat Dari Mesir. Merupakan surat balasan dari Saleh untuk tokoh 'Saya', tentang dukungannya untuk membuat hikayat tentang Hamid dan Zainab, dia juga tak lupa melampirkan surat-surat semasa masih di Mekah.

Jika dilihat dari urutan peristiwa-peristiwa pokok tersebut, maka Hamka menggunakan alur cerita yang besifat sorot balik (flash back). Di dalam novelnya, Hamka memulai cerita dari peristiwa (20), yang merupakan ahir cerita sesungguhnya. Urutan alur yang disajikan di dalam novel tersebut menjadi : (20), (11), (12), (13), (10), (14), (1), (2), (3), (4), (5), (6), (7), (8), (9), (15), (16), (17), (18), dan (19). Dalam DBLK, Hamka juga menceritakan peristiwa tokoh Zainab, tanpa kehadiran tokoh Hamid, yaitu pada saat pengungkapan perasaan hatinya pada saat berdialog dengan Rosna. Oleh karena itu, selain beralur sorot balik, novel $D B L K$ juga memiliki alur jamak.

Rangkaian peristiwa utama yang terdapat di dalam novel novel Perempuan Berkalung Sorban jika diurutkan sesuai dengan tata-waktunya adalah sebagai berikut:

(1) Anisa Nuhaiyyah adalah seorang anak kiai dari sebuah pondok pesantren di Jawa Timur.

(2) Anisa mempunyai paman bernama Khudori. Dengannya Anisa belajar naik kuda dan memperoleh kisah-kisah perjuangan wanita, meskipun ia dilarang belajar naik kuda oleh ayahnya dengan alasan naik kuda hanya boleh dilakukan oleh laki-laki. Diam-diam Anisa mengagumi sosok pamannya itu. Begitu juga dengan Khudori, menyukai Anisa yang terpaut usia jauh dengannya.

(3) Setamat mondok di Gontor, Khudori melanjutkan beasiswanya di AlAzhar, Kairo. Kepergian sementara Khudori itu menyisakan kerinduan dan kekosongan hari-hari Anisa.

(4) Anisa selalu disuruh berkutat dengan pekerjaan wanita, seperti urusan dapur. Tidak seperti kedua kakaknya, Rizal dan Wildan, yang bebas melakukan hal kesukaan mereka. Ia mendapatkan materi di pondok yang mengatakan wanita lebih lemah dibandingkan dengan laki-laki, baik dari segi amal agama, pendidikan, dan sebagainya. Hal tersebut membuat Anisa bertanya-tanya mengapa wanita dibedakan dengan laki-laki, padahal mereka sama-sama makhluk ciptaan Allah dan juga mendorongnya untuk merombak perlakuan yang membedakan wanita dengan laki-laki itu.

(5) Pada suatu waktu ada keluarga yang melamar Anisa untuk anaknya, Samsudin. Awalnya, orangtua Anisa menolak karena Anisa masih terlalu kecil dan belum mengerti apa-apa. Namun, ayah Samsudin yang 
merupakan teman karib Kiai Hanan ketika mondok mengatakan akan menunggu Nisa sampai waktunya. Sampai pada saat Anisa baligh dan Samsudin diwisuda, pernikahan tanpa cinta itu pun dilangsungkan.

(6) Selama menikah dengan Samsudin, Anisa tidak pernah mendapat kebahagiaan dan perlakuan yang baik, ia mendapat perlakuan kasar yang tidak manusiawi dari suaminya. Malah karena Anisa dianggap mandul, Samsudin menikah lagi dengan seorang janda yang bernama Kalsum dan mempunyai anak yang dinamai Fadilah.

(7) Kisah pahitnya itu Anisa ceritakan pada Khudori lewat surat. Ia ingin menceritakan kepada ibunya, tapi takut ibunya tidak akan percaya dan menyuruhnya bersabar karena kodrat wanita adalah tetap bersabar dalam keadaan apapun.

(8) Khudori pulang dari Kairo. Dengan bantuan Khudori, Anisa menceritakan kehidupannya selama menikah dengan Samsudin kepada ibunya, Hj. Mutma'inah. Betapa terkejutnya ia mendengar cerita Anisa. Begitu pun dengan ayahnya, hingga terserang darah tinggi saat mendengar kabar tersebut.

(9) Keluarga Anisa mengirim Kiai Shaleh untuk merundingkan masalah dalam pernikahan Anisa dan Samsudin dengan pihak keluarga Kiai Nasiruddin. Akhirnya disepakati perceraian Anisa dengan Samsudin

(10) Akhirnya Anisa menyandang status janda. Ia menjadi semakin dekat dengan Khudori dan sering pergi berdua mencari angin segar.

(11) Anisa yang masih menggebu menuntut ilmu, melanjutkan kuliahnya di Jogja dan mengambil jurusan filsafat.

(12) Khudori mengunjunginya di tempat kos dan mengajak Anisa menikah. Kemudian mereka pun direstui dan melangsungkan pernikahan yang membawa kebahagiaan bagi keduanya.

(13) Selama beberapa tahun menikah, Anisa belum juga dikaruniai momongan. Hal itu membuat berbagai gunjingan menimpa dirinya. Ia mencoba bersabar.

(14) Sampai pada suatu hari ia mendengar kabar bahwa Khudori pernah menikah di Berlin dan punya seorang anak. Dan karena Anisa mandul, Khudori berniat untuk rujuk kembali dengan istri pertamanya.

(15) Pada sebuah acara konferensi perempuan muslim internasional, Anisa bertemu dengan peserta dari Yordania, bernama Loubna el Huraybi. yang merupakan teman akrab Khudori ketika di Berlin. Loubna mengaku tidak pernah mengetahui pernikahan itu.

(16) Anisa meminta maaf pada Khudori. Hubungan mereka kembali harmonis dan semakin mesra. Tak lama kemudian Anisa hamil dan melahirkan seorang anak yang mereka namai Mahbub.

(17) Anisa dan Khudori dengan membawa Mahbub menghadiri sebuah acara pernikahan teman sekolah. Secara tidak sengaja mereka bertemu dengan Samsudin dan Kalsum yang juga membawa Fadilah. Anisa melihat masih ada dendam dari mata Samsudin.

(18) Sampai pada suatu hari, Anisa mendapat kabar dari rumah sakit yang mengabarkan bahwa Khudori mengalami kecelakaan dan sedang 
dirawat di ruang ICU Rumah Sakit Sardjito. Khudori yang megalami kritis tidak kuat dan akhirnya meninggal dalam keadaan tersenyum dan tenang.

(19) Anisa yang telah memiliki Mahbub awalnya sangat terpukul dan tidak percaya bahwa suaminya meninggal. Tapi kepergian jasad suaminya itu tak memutuskan kebersamaan jiwa mereka.

(20) Annisa masih selalu teringat masa lalunya tersebut, "Dan kini, setelah aku mendapatkan gelar, sudah memiliki Mahbub anak semata wayang, cerita itu sering muncul seturut dengan pengetahuan yang kudapatkan dari buku kehidupan"

Berdasarkan rangkaian peristiwa-peristiwa di atas, dapat diketahui bahwa Adibah El Halieqy membangun alur cerita dimulai dari peristiwa (20), kemudian secara runtut menuju ke peristiwa (1), (2) dan seterusnya sampai peristiwa (19). Oleh karena itu, alur yang digunakan oleh Adibah adalah alur sorot balik (Flash back). Semua peristiwa yang ditampilkan, selalu melibatkan tokoh utamanya, yaitu Annisa, sehingga selain memiliki alur sorot balik novel $P B S$ hanya memiliki alur tunggal.

Uraian mengenai alur/plot dari kedua novel di atas, dapat disimpulkan novel bahwa novel DBLK merupakan hipogram bagi PBS dalam unsur alur/plot, yaitu alur sorot balik dan ada transformasi bersifat modifikasi di dalamnya, yaitu menjadi alur tunggal.

\section{Intertekstual dalam Tokoh}

Perbedaan dalam unsur tokoh utama sangat jelas terlihat di dalam kedua novel. Tokoh utama pria yang dicintai oleh Zainab pada $D B L K$ merupakan lelaki dari status sosial yang lebih rendah yaitu Hamid, sebagai anak yatim piatu yang dijadikan anak angkat oleh ayahnya Zainab. Walaupun Hamid memiliki rasa cinta terhadap Zainab, tetapi tidak memiliki keberanian untuk menyatakan perasaan cintanya kepada Zainab, karena kuatnya belenggu rasa rendah dirinya. Sedangkan dalam novel $P B S$, tokoh yang dicintai Annisa, yaitu Lek Khudori merupakan lelaki dari status sosial yang sama dengan keluarga ayahnya Annisa, dan memiliki keberanian dalam hal mengutarakan perasaannya terhadap Annisa.

Tokoh yang menjadi pasangan pernikahan paksa dalam DBLK, yaitu kemenakan ayahnya Zainab, merupakan sosok yang berpengetahuan tinggi sehingga mau menerima dengan ikhlas terhadap penolakan Zainab, dan lebih memilih untuk tetap menjadi saudara, sedangkan pada PBS, sosok Samsudin merupakan sosok antagonis.

Dari tokoh utama wanita, yaitu Zainab dan Annisa, keduanya memiliki karakter yang berbeda. Zainab, walaupun digambarkan sebagai sosok wanita lembut dan penurut, tetapi berani melawan tradisi untuk menolak adanya kawin paksa, sedangkan Annisa, walalupun digambarkan sebagai perempuan cerdas dan pemberontak, tetapi tidak memiliki kekuatan untuk menolak kawin paksa tersebut.

Berdasarkan uraian di atas, dalam hal tookoh dan penokohan, novel $P B S$ merupakan transformasi konversi terhadap $D B L K$.

\section{Intertekstual dalam Sudut Pandang}

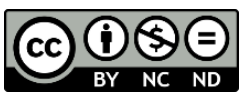

Creative Commons Attribution-NonCommercial-NoDerivatives 4.0 International License 
Sudut pandang atau point of view, mengacu pada cara sebuah cerita dikisahkan atau pandangan yang digunakan pengarang sebagai sarana untuk menyajikan tokoh, tindakan, latar, dan berbagai peristiwa yang mernbentuk cerita dalam sebuah karya fiksi novel kepada pembaca. Dengan demikian sudut pandang pada hakikatnya merupakan strategi, teknik, siasat, yang secara sengaja dipilih oleh pengarang untuk mengemukakan gagasan dan ceritanya. Sudut pandang pengarang baik dalam novel DBLKmaupun PBS, keduanya menggunakan sudut pandang orang pertama "akuan" dan menyebutkan nama "diaan". Sudut pandang ini pengarang menampilkan tokoh-tokoh cerita dengan sebutan kata saya dan nama orang.

Perbedaan hanya pada cara penyampaiannya. Pada $P B S$, pengarang sendiri seolah-olah menjadi tokoh utama. Sedangkan pada $D B L K$, pengarang seperti seorang penulis biografi Hamid, atau dalam isi cerita $D B L K$ seolah-olah menjadi tokoh sahabat Hamid.

\section{SIMPULAN}

Hasil kajian menunjukkan bahwa Perempuan Berkalung Sorban memiliki hubungan intertekstual dengan novel Di Bawah Lindungan Kabah sebagai hipogramnya dalam hal tema, alur dan sudut pandang. Dalam hal tema, novel $P B S$ merupakan transformasi bersifat pengembangan dalam hal tradisi pinggitan, dan transformasi konversi pada tradisi kawin paksa dari $D B L K$ sebagai hipogramnya. Dalam unsur alur/plot, $P B S$ merupakan transformasi modifikasi terjadap alur DBLK sebagai hipogramnya, yaitu hanya memiliki alur tunggal. DBLK menjadi hipogram $P B S$ dalam unsur sudut pandang, yang membedakan adalah pada PBS, pengarang seolah menjadi tokoh utama itu sendiri.

\section{DAFTAR PUSTAKA}

Djamaris E., (1997). Filologi dan Cara Kerja Penelitian Filologi, Bahasa dan Sastra Jakarta: CV. Manasco.

El Khalieqy A., (2009). Perempuan llerkalung Sorban. Yogyakarta: Arti Bumi Intaran.,

Gyem K.J., (2005). Hubungan Intertekstualitas Di Antara Novel-Novel Mochtar Lubis. Wacana. Vol 7 (1): 31-49.

Hamka. (2017). Di Bawah Lindungan Kabah. Cetakan 1. Jakarta. Grma Insani.

Junus U., (1984). Sejarah Melayu menemukan Diri kembali. Kuala Lumpur. Fajar Bakti, Sdn Bhd.

Pradopo, R.D. (2003). Beberapa Teori Sastra. Metode Kritik, dan Penerapannya. Yogyakarta: Pustaka Pelajar Offset.

Pradopo R.D., (2002). Kritik Sastra Indonesia Modern. Yogyakarta: Gama Media.

Riffaterre, M. (1978). Semiotics of Poetry. Bloomington \& London: Indiana University Press

Robson, S.O., (1978). Pengkajian Sastra-Sastra Tradisional Indonesia. Bahasa dan Sastra Th. IV (6) :3-48. 
Diskursus: Jurnal Pendidikan Bahasa Indonesia

Vol. 3, No. 3, Desember 2020, pp. 213-225

p-ISSN: 2615-4935

e-ISSN: 2615-4943

Sastrowardoyo S., (1983). Sastra Hindia Belanda dan Kita. Jakarta: Balai Pustaka Teeuw A. (1982). Khazanah Sastra Indonesia. Jakarta: Balai pustaka.

Teeuw A. (1983). Sastra dan Ilmu Sastra: Pengantar Teori Sastra. Jakarta: Pustaka Jaya.

Zulhelmi. (2016). Orisinalitas Dan Krestivitas Dalam Karya Sastra: Studi perbandingan antara novel Zaynab karya Haykal dengan roman Di Bawah Lindungan Ka'bah karya Hamka. Ar-Rairy Intemational Conference on Islamic Study (ARICIS). Vol 1: 415- 436. 